\title{
Amblyomma nodosum (Neumann, 1899): observations on life cycle under laboratory conditions
}

\author{
Amblyomma nodosum (Neumann, 1899): observações sobre o ciclo biológico em condiçôes de laboratório
}

Michele da Costa Pinheiro ${ }^{1 *}$; Elizabete Captivo Lourenço ${ }^{1}$; Iwine Joyce Barbosa de Sá-Hungaro ${ }^{1}$; Kátia Maria Famadas ${ }^{1}$

${ }^{1}$ Laboratório de Artrópodes Parasitos, Programa de Pós-Graduação em Ciências Veterinárias, Departamento de Parasitologia Animal, Universidade Federal Rural do Rio de Janeiro - UFRRJ, Seropédica, RJ, Brasil

Received December 8, 2014

Accepted February 13, 2015

\begin{abstract}
The natural hosts of Amblyomma nodosum in the immature stages are a variety of birds and the anteater in the adult stage. However, so far no data have been published about this tick's life cycle. To fill this gap, a record was made of its development under laboratory conditions. All the procedures were controlled in a BOD chamber set at $27 \pm 1{ }^{\circ} \mathrm{C}$ and $80 \pm 10 \%$ relative humidity and scotophase. The parasitic stages were raised on rabbits (Oryctolagus cuniculus Linnaeus, 1758), from which more than $50 \%$ of larvae and nymphs were recovered, although only a small portion performed ecdysis. The adults did not fixed on the rabbits, which suggests that the experimental conditions were unsuitable for the requirements of this species. The data obtained here indicate that $A$. nodosum is highly dependent on its host and environment whereas under laboratory conditions and host chosen for the study was not obtained satisfactory results and new studies with different hosts and new environmental conditions should be elaborated.
\end{abstract}

Keywords: Tick, host, biology, Brazil, Amblyomma nodosum.

\section{Resumo}

Os hospedeiros naturais de Amblyomma nodosum, nos estágios imaturos, são uma variedade de pássaros e, na fase adulta, são os tamanduás. No entanto, até agora não há dados publicados sobre o ciclo de vida desse carrapato. Para preencher essa lacuna, um registro foi realizado sobre o desenvolvimento em condiçóes de laboratório. Todos os procedimentos foram controlados em câmaras tipo BOD a $27 \pm 1^{\circ} \mathrm{C}$ e $80 \pm 10 \%$ de umidade relativa e escotofase. As fases parasitárias foram desenvolvidas em coelhos (Oryctolagus cuniculus Linnaeus, 1758), a partir dos quais mais de $50 \%$ das larvas e ninfas foram recuperados, embora apenas uma pequena porção tenha realizado ecdise. Os adultos não se fixaram nos coelhos, o que sugere que as condiçóes experimentais eram inadequadas para os requisitos dessa espécie. Os dados obtidos indicam que $A$. nodosum é altamente dependente de seu hospedeiro e ambiente, enquanto em condiçóes de laboratório e pela escolha do hospedeiro para o estudo não foram obtidos resultados satisfatórios, e novos estudos com diferentes hospedeiros e novas condiçôes ambientais devem ser elaborados.

Palavras-chave: Carrapato, hospedeiro, biologia, Brasil, Amblyomma nodosum.

Amblyomma nodosum (Neumann, 1899) is a an ixodid tick restricted to the Neotropical region (GUGLIELMONE et al., 2003; NAVA et al., 2007), whose hosts are the mammals Tamandua (Linnaeus, 1758) and Myrmecophaga (Linnaeus, 1758) in the adult stage and a variety of birds in the immature stages (JONES et al., 1972; BECHARA et al., 2002; MARTINS et al., 2004; LABRUNA et al., 2007; OGRZEWALSKA et al., 2009; LUZ et al., 2012; PASCOAL et al., 2013; TORGA et al., 2013; GARCIA et al., 2013; MARTINS et al., 2014).

*Corresponding author: Michele da Costa Pinheiro. Laboratório de Artrópodes Parasitos, Departamento de Parasitologia Animal, Universidade Federal Rural do Rio de Janeiro - UFRRJ, BR-465, Km 07, CEP 23890-000, Seropédica, RJ, Brasil.

e-mail: michelezootec@gmail.com
Although there are no reports of $A$. nodosum acting as a vector of pathogens, isolates of Rickettsia parkeri and Rickettsia bellii have been obtained from specimens collected in passerine birds caught in the Atlantic Forest, and from Tamandua tetradactyla (Linnaeus, 1758) in the Pantanal wetland of southern Mato Grosso (OGRZEWALSKA et al., 2009; ALMEIDA et al., 2013). These findings place $A$. nodosum on the list of species that may be important in the epidemiology of rickettsial diseases that have been little studied.

Information on $A$. nodosum in the scientific literature covers the morphology, taxonomy and records of surveys on fauna of ixodid ticks (SERRA-FREIRE et al., 1993; AMORIM \& SERRA-FREIRE, 1994; BITENCOURTH et al., 2007), but data on its biological cycle have yet to be reported. 
Biological data on Neotropical ticks is usually difficult to obtain because most of the species are heteroxenous, their hosts are wild animals, and they live in ecosystems in which the microclimates required for their development are also often unknown. In view of this shortcoming, a record was made of its development under laboratory conditions.

An engorged female of $A$. nodosum was collected from a giant anteater (Myrmecophaga tridactyla) at the Wild Animal Screening Center (CETAS- IBAMA), which receives animals captured in the metropolitan region of Rio de Janeiro. The specimen was sent to Laboratory of Ixodology at the Federal Rural University of Rio de Janeiro, where it was washed with water and hypochlorite, blotted dry, identified following Onofrio et al. (2006) and placed in a Petri dish, and fixed in the supine position using adhesive tape.

During the life cycle, both the female $A$. nodosum and the other non-parasitic stages were kept in controlled laboratory conditions in a acclimatized BOD (Biochemical Oxygen Demand) chamber, set at a temperature of $27 \pm 1{ }^{\circ} \mathrm{C}, 80 \pm 10 \%$ relative humidity and scotophase. The parasitic stages were raised on rabbits (Oryctolagus cuniculus Linnaeus, 1758) without prior contact with ticks or acaroids. Notes were taken daily during all the experimental steps. Infestations were recorded according to the method described by Neitz et al. (1971).

The total egg mass of the female $A$. nodosum was collected and placed in $10 \mathrm{ml}$ disposable plastic syringes, which were cut off close to the plunger, closed with cotton wool, and again placed in the BOD chamber. Larval hatching was recorded, and 15 to 20-day-old larvae were raised on the rabbits. After dropping off the hosts spontaneously, the engorged larvae were collected, treated in the same way as the eggs, and kept in an incubator until the nymphs finished molting.

Fifteen to 20-day post-ecdysial nymphs were raised on rabbits and, after dropping off spontaneously, were stored in syringes and placed in the BOD chamber. Adult ecdysis was recorded and at 20 to 25 days the adults were placed on the host's back (NEITZ et al., 1971). The biological parameters evaluated here were the ones assessed by Chacón et al. (2003) and Bellato \& Daemon (1997).

The present study was approved by the Ethics Committee on the Use of Animals at the Federal Rural University of Rio de Janeiro/COMEP, under process number 160/2011. The rabbits were given water and commercial feed pellets ad libitum.

The total weight of the egg mass produced by the female A. nodosum was $593.10 \mathrm{mg}$, from which 792 (256.3 mg) larvae hatched. After feeding on the rabbits, 413 (52.1\%) engorged larvae were recovered. Twenty-five nymphs molted (6.05\%), from which 14 (56\%) engorged nymphs $(89.7 \mathrm{mg})$ were recovered after infestation and spontaneous dropping off the hosts. Seven adult $A$. nodosum emerged, two females and five males, representing a total molt rate of $50 \%$. The adults did not fixed on the rabbits (Table 1).

The life cycle of $A$. nodosum in the laboratory did not complete one generation, presenting difficulties in its evolution, which suggests that the experimental conditions were unsuitable for the requirements of this species.

As for the immature stages of $A$. nodosum, it was possible to recover more than $50 \%$ of the specimens, which is comparable to the range of recovery of other Neotropical species of Amblyomma raised in the laboratory under similar conditions (SANAVRIA \& PRATA, 1996; LABRUNA et al., 2002a, 2004; PINTER et al., 2004; FACCINI et al., 2010; MARTINS et al., 2012; GERARDI et al., 2013). The immature stages of $A$. nodosum parasitize several species of birds, showing low specificity (LABRUNA et al., 2007; OGRZEWALSKA et al., 2009, LUZ et al., 2012; PASCOAL et al., 2013; TORGA et al., 2013; NAVA \& GUGLIELMONE, 2013). Rabbits are routinely used as experimental hosts to raise the different stages of several tick species (SANAVRIA \& PRATA, 1996; PRATA et al., 1998; FACCINI et al., 2010; PINHEIRO et al., 2013). Although more than half of the larvae were recovered, only a small portion $(6 \%)$ molted. This may be attributed to incomplete and improper feeding by the tick because rabbits are not natural hosts, or because the climatic parameters did not favor the continuity of the cycle. As most ticks spend the best part of their life away from the host, climate conditions such as temperature and humidity are important factors for the success of the cycle. Randolph (2004) pointed out that these factors and others such as seasonality, search time to find a host, and mortality, influence the life cycle. In this study, a temperature of $27 \pm 1{ }^{\circ} \mathrm{C}$ and relative humidity of $80 \pm 10 \%$ were used to raise $A$. nodosum, since these values are used to breed most Neotropical ticks (Amblyomma parvum Aragão 1908 - GUGLIELMONE et al., 1991; OLEGÁRIO et al., 2011; Amblyomma aureolatum - RODRIGUES et al., 2002; Amblyomma tigrinum Koch 1844 - LABRUNA et al., 2002b; CARDOSO et al., 2008; Amblyomma triste - LABRUNA et al., 2003; Amblyomma cooperi Nuttal; Warburton, 1908 - LABRUNA et al., 2004; Amblyomma incisum Neumann, 1906 - SZABÓ et al., 2009;

Table 1. Biological parameters of Amblyomma nodosum ticks raised on rabbits in the laboratory $\left(27 \pm 1^{\circ} \mathrm{C}, 80 \% \mathrm{RH}\right.$ and scotophase).

\begin{tabular}{lccc}
\hline \multicolumn{1}{c}{ Biological parameters } & Larvae & Nymphs & Adults \\
\hline $\begin{array}{l}\text { Pre-oviposition period (days) } \\
\text { period (days)+(dias) }\end{array}$ & - & - & 3 \\
Oviposition period (days) & - & - & 18 \\
Egg hatching period (days) hatching(days) & $11 \pm 1.73(10-13)$ & - & - \\
Feeding period (days) & $6.5 \pm 0.70(6-7)$ & $10.33 \pm 2.08(8-12)$ & - \\
Ecdysis period (days) & $10.66 \pm 1.15(10-12)$ & $22.62 \pm 10.69(11-32)$ & - \\
Ticks recovered (\%) & 36.67 & 56 & - \\
\hline
\end{tabular}

Values are presented as mean \pm SE (range in parentheses). 
Amblyomma auricularium - FACCINI et al., 2010; and Amblyomma ovale-MARTINS et al., 2012). However, other values for these variables may be tested to determine the best conditions for the development of this species.

Rabbits were not good hosts for the adult ticks, since in these conditions no individual of $A$. nodosum showed any stimulus or action to feed. The host species for this stage appear to be restricted to those within the superorder Xenarthra, particularly Myrmecophagidae (JONES et al., 1972; BECHARA et al., 2002; MARTINS et al., 2004, 2014; GARCIA et al., 2013). Occasional records of hosts such as the six-banded armadillo Euphractus sexcinctus (Linnaeus, 1758) (BECHARA et al., 2002) and dogs can be considered accidental (MAZIOLI et al., 2012). Nava $\&$ Guglielmone (2013) consider that ticks do not generally show high host specificity, and that ecological factors such as habitat specificity, time elapsed between generations, the free-living stage, and the type of cycle are more important than host selectivity. Therefore, A. nodosum, a characteristic tick of the Cerrado biome, probably prefers drier and warmer environments (OGRZEWALSKA et al., 2009). However, there are no studies that address the climate requirements of free-living $A$. nodosum.

The data obtained here indicate that the $A$. nodosum life cycle is highly dependent on its host and environment whereas under laboratory conditions and host chosen for the study was not obtained satisfactory results. Although it was not possible to complete the cycle of $A$. nodosum due to the low number of adults and their non-attachment on the rabbits, the data may contribute to the body of knowledge about its biology and to new attempts to raise it in the laboratory. While not representative of the reality of the A. nodosum life cycle in natural conditions, data obtained in the laboratory are one of the most common ways to make inferences about tick biology, particularly those that parasitize wild animals, and serve to underpin predictive studies.

\section{References}

Almeida RF, Garcia MV, Cunha RC, Matias J, Labruna MB, Andreotti R. The first report of Rickettsia spp. in Amblyomma nodosum in the State of Mato Grosso do Sul, Brazil. Ticks Tick Borne Dis 2013; 4(1-2): 156-159.

Amorim M, Serra-Freire NM. Amblyomma nodosum Neumann, 1899 descrição morfológica do estádio de larva. Rev Bras Parasitol Vet 1994; 3(2): 131-142.

Bechara GH, Szabó MPJ, Almeida WV Fo., Bechara JN, Pereira RJG, Garcia JE, et al. Ticks associated with armadillo (Euphractus sexcinctus) and anteater (Myrmecophaga tridactyla) of Emas National Park, State of Goias, Brazil. Ann N Y Acad Sci 2002; 969(1): 290-293. http://dx.doi. org/10.1111/j.1749-6632.2002.tb04394.x. PMid:12381607

Bellato V, Daemon E. Efeito de três temperaturas sobre a fase não parasitária de Rhipicephalus sanguineus (Latreille, 1806) (Acari: Ixodidae). Rev Bras Parasitol Vet 1997; 6(1): 21-27.

Bitencourth K, Teixeira RHF, Amorim M, Gazêta GS, Serra-Freire NM. Análise do número de cerdas internas do órgão de Haller de larvas de Amblyomma nodosum Neumann (Acari, Ixodidae). Rev Bras Entomol 2007; 51(1): 58-61. http://dx.doi.org/10.1590/S0085-56262007000100010.

Cardoso CP, Stalliviere FM, Schelbauer CA, Souza AP, Bellato V, Sartor AA. Amblyomma tigrinum no Município de Lages, SC e observaçóes da biologia em condiçôes de laboratório. Rev Bras Parasitol Vet 2008; 17(1): 56-58. http://dx.doi.org/10.1590/S1984-29612008000100013. PMid:18554444

Chacón SC, Correia PG, Barbieri FS, Daemon E, Faccini JLH. Efeito de três temperaturas constantes sobre a fase não parasitária de Amblyomma cajennense (Fabricius,1787) (Acari: Ixodidae). Rev Bras Parasitol Vet 2003; 12(1): 13-20.

Faccini JLH, Cardoso ACB, Onofrio VC, Labruna MB, Barros-Battesti DM. The life cycle of Amblyomma auricularium (Acari: Ixodidae) using rabbits (Oryctolagus cuniculus) as experimental host. Exp Appl Acarol 2010; 50(1): 71-77. http://dx.doi.org/10.1007/s10493-009-9281-z. PMid: 19554463

Garcia MV, Silva DC, Almeida RFC, Cunha RC, Matias J, Barros JC, et al. Environmentally associated ticks (Acari: Ixodidae) in Campo Grande, Mato Grosso do Sul, Brazil. Rev Bras Parasitol Vet 2013; 22(1): 124-128. http://dx.doi.org/10.1590/S1984-29612013000100023. PMid:24252958

Gerardi M, Martins MM, Nava S, Szabó MP. Comparing feeding and reproductive parameters of Amblyomma parvum tick populations (Acari: Ixodidae) from Brazil and Argentina on various host species. Vet Parasitol 2013; 197(1-2):312-317. http://dx.doi.org/10.1016/j.vetpar.2013.06.018. PMid:23906808

Guglielmone AA, Estrada-Peña A, Keirans JE, Robbins RG. Ticks (Acari: Ixodida) of the Neotropical Zoogeographic Region. Atalanta: International Consortium on Ticks and Tickborne Diseases; 2003. 173 p.

Guglielmone AA, Mangold AJ, Garcia MD. The life cycle of Amblyomma parvum Aragao, 1908 (Acari: Ixodidae) under laboratory conditions. Exp Appl Acarol 1991; 13(2): 129-136. http://dx.doi.org/10.1007/ BF01193663. PMid:1786743

Jones EK, Clifford CM, Keirans JE, Kohls GM. The ticks of Venezuela (Acarina: Ixodoidea) with a key to the species of Amblyomma in the western hemisphere. Brigham Young Univ Sci Bull Biol Ser 1972; 17(4): 1-40.

Labruna MB, Fugisaki EY, Pinter A, Duarte JM, Szabó MJ. Life cycle and host specificity of Amblyomma triste (Acari: Ixodidae) under laboratory conditions. Exp Appl Acarol 2003; 30(4): 305-316. http:// dx.doi.org/10.1023/B:APPA.0000006514.02451.6d. PMid:14756395

Labruna MB, Kasai N, Ferreira F, Faccini JLH, Gennari SM. Seasonal dynamics of ticks (Acari: Ixodidae) on horses in the state of São Paulo, Brazil. Vet Parasitol 2002a; 105(1): 65-77. http://dx.doi.org/10.1016/ S0304-4017(01)00649-5. PMid:11879967

Labruna MB, Souza SLP, Menezes AC, Horta MC, Pinter A, Gennari SM. Life-cycle and host specificity of Amblyomma tigrinum (Acari: Ixodidae) under laboratory conditions. Exp Appl Acarol 2002b; 26(1-2): 115-125. http://dx.doi.org/10.1023/A:1020957122256. PMid:12475081

Labruna MB, Pinter A, Teixeira RHF. Life cycle of Amblyomma cooperi (Acari: Ixodidae) using capybaras (Hydrochaeris hydrochaeris) as hosts. Exp Appl Acarol 2004; 32(1-2): 79-88. http://dx.doi.org/10.1023/ B:APPA.0000018228.05088.26. PMid:15139274

Labruna MB, Sanfilippo LF, Demetrio C, Menezes AC, Pinter A, Guglielmone AA, et al. Ticks collected on birds in the state of São Paulo, Brazil. Exp ApplAcarol 2007; 43(2): 147-160. http://dx.doi.org/10.1007/ s10493-007-9106-x. PMid:17882514

Luz HR, Faccini JLH, Landulfo GA, Berto BP, Ferreira I. Bird ticks in an area of the Cerrado of Minas Gerais State, southeast Brazil. Exp Appl Acarol 2012; 58(1): 89-99. http://dx.doi.org/10.1007/s10493-0129572-7. PMid:22729500 
Martins JR, Medri IM, Oliveira CM, Guglielmone A. Occurrence of ticks on giant anteater (Myrmecophaga tridactyla) and collared anteater (Tamandua tetradactyla) in the Pantanal region of Mato Grosso do Sul State, Brazil. Ciênc Rural 2004; 34(1): 293-295. http://dx.doi.org/10.1590/ S0103-84782004000100048.

Martins TF, Moura MM, Labruna MB. Life-cycle and host preference of Amblyomma ovale (Acari: Ixodidae) under laboratory conditions. Exp Appl Acarol 2012; 56(2): 151-158. http://dx.doi.org/10.1007/s10493011-9506-9. PMid:22113779

Martins TF, Venzal JM, Terassini FA, Costa FB, Marcili A, Camargo LMA, et al. New tick records from the state of Rondônia, western Amazon, Brazil. Exp Appl Acarol 2014; 62(1): 121-128. http://dx.doi. org/10.1007/s10493-013-9724-4. PMid:23975565

Mazioli R, Szabó M, Mafra C. Amblyomma nodosum (Acari: Ixodidae) parasitizing a domestic dog in Colatina, Espírito Santo, Brazil. Rev Bras Parasitol Vet 2012; 21(4): 428-432. http://dx.doi.org/10.1590/S198429612012005000006. PMid:23207985

Nava S, Guglielmone AA. A meta-analysis of host specificity in Neotropical hard ticks (Acari: Ixodidae). Bull Entomol Res 2013; 103(2): 216-224. http://dx.doi.org/10.1017/S0007485312000557. PMid:22954015

Nava S, Lareschi M, Rebollo C, Benítez Usher C, Beati L, Robbins RG, et al. The ticks (Acari: Ixodida: Argasidae, Ixodidae) of Paraguay. Ann Trop Med Parasitol 2007; 101(3): 255-270. http://dx.doi. org/10.1179/136485907X176319. PMid:17362600

Neitz WO, Boughton F, Walters HS. Laboratory investigations on the life-cycle of the Karoo paralysis tick (Ixodes rubicundus Neumann, 1904). Onderstepoort J Vet Res 1971; 38(3): 215-223. PMid:5164824.

Ogrzewalska M, Pacheco RC, Uezu A, Richtzenhain LJ, Ferreira F, Labruna MB. Rickettsial infection in Amblyomma nodosum ticks (Acari: Ixodidae) from Brazil. Ann Trop Med Parasitol 2009; 103(5): 413-425. http://dx.doi.org/10.1179/136485909X451744. PMid:19583912

Olegário MMM, Gerardi M, Tsuruta SA, Szabó MPJ. Life cycle of the tick Amblyomma parvum Aragão, 1908 (Acari: Ixodidae) and suitability of domestic hosts under laboratory conditions. Vet Parasitol 2011; 179(1-3): 203-208. http://dx.doi.org/10.1016/j.vetpar.2011.01.056. PMid:21353392

Onofrio VC, Labruna MB, Pinter A, Giacomin FG, Barros-Battesti D. Comentários e chaves para as espécies do gênero Amblyomma. In: BarrosBattesti DM, Arzua M, Bechara, GH, editors. Carrapatos de importância médico-veterinária da Regiāo Neotropical: um guia ilustrado para identificação de espécies. São Paulo: Vox;ICTTD-3;Butantan; 2006. p. 53-113.
Pascoal JO, Amorim MP, Martins MM, Melo C, Silva EL Jr., Ogrzewalska $\mathrm{M}$, et al. Ticks on birds in a savanna (Cerrado) reserve on the outskirts of Uberlândia, Minas Gerais, Brazil. Rev Bras Parasitol Vet 2013; 22(1): 46-52. http://dx.doi.org/10.1590/S1984-29612013005000004. PMid:23471429

Pinheiro MC, Sá IJB, Ribeiro CCDU, Martins CD, Raia VA, Famadas K. Prognosing the sex of adults of Amblyomma auricularium through evaluating the biological parameters of engorged nymphs. Ciênc Rural 2013; 43(4): 662-667. http://dx.doi.org/10.1590/S0103-84782013000400015.

Pinter A, Dias RA, Gennari SM, Labruna MB. Study of the seasonal dynamics, life cycle, and host specificity of Amblyomma aureolatum (Acari: Ixodidae). J Med Entomol 2004; 41(3): 324-332. http://dx.doi. org/10.1603/0022-2585-41.3.324. PMid:15185932

Prata MCA, Faccini JLH, Daemon E. Relationship between weight and number of engorged Amblyomma cajennense larvae and nymphs (Fabricius, 1787) (Acari: Ixodidae) in experimental infestations on rabbits. Rev Bras Parasitol Vet 1998; 7(2): 107-111.

Randolph SE. Tick ecology: processes and patterns behind the epidemiological risk posed by ixodid ticks as vectors. Parasitology 2004;129(7 Suppl): S37-S65. http://dx.doi.org/10.1017/S0031182004004925. PMid:15938504

Rodrigues D, Avila de Carvalho H, Almeida Fernandes A, Freitas CMV, Cerqueira Leite R, Oliveira PR. Biology of Amblyomma aureolatum (Pallas, 1772) (Acari: Ixodidae) on some laboratory hosts in Brazil. Mem Inst Oswaldo Cruz 2002; 97(6): 853-856. http://dx.doi.org/10.1590/ S0074-02762002000600018. PMid:12386709

Sanavria A, Prata MCA. Metodologia para colonização do Amblyomma cajennense (Fabricius, 1787) (Acari: Ixodidae) em laboratório. Rev Bras Parasitol Vet 1996; 5(2): 87-90.

Serra-Freire NM, Peixoto BTM, Oliveira VL, Teixeira RH. Amblyomma nodosum Neumann, 1899: contribuição ao estudo morfológico de machos e fêmeas. Rev Bras Parasitol Vet 1993; 2(2): 105-108.

Szabó MP, Pereira LF, Castro MB, Garcia MV, Sanches GS, Labruna MB. Biology and life cycle of Amblyomma incisum (Acari: Ixodidae). Exp Appl Acarol 2009; 48(3): 263-271. http://dx.doi.org/10.1007/s10493008-9234-y. PMid:19130270

Torga K, Tolesano-Pascoli G, Vasquez JB, Silva EL Jr., Labruna MB, Martins TF, et al. Ticks on birds from Cerrado forest patches along the Uberabinha river in the Triângulo Mineiro region of Minas Gerais, Brazil. Ciênc Rural 2013; 43(10): 1852-1857. http://dx.doi.org/10.1590/ S0103-84782013005000121. 